\title{
Analysis of DNA Damage Responses After Boric Acid-mediated Boron Neutron Capture Therapy in Hepatocellular Carcinoma
}

\author{
KUAN-HAO CHEN ${ }^{1 *}$, ZIH-YIN LAI $^{1 *}$, DING-YU LI ${ }^{1}$, YU-CHUAN LIN $^{2}$, \\ FONG-IN CHOU ${ }^{2}$ and YUNG-JEN CHUANG ${ }^{1}$ \\ ${ }^{1}$ Department of Medical Science and Institute of Bioinformatics and Structural Biology, \\ National Tsing Hua University, Hsinchu, Taiwan, R.O.C.; \\ ${ }^{2}$ Nuclear Science and Technology Development Center, National Tsing Hua University, Hsinchu, Taiwan, R.O.C.
}

\begin{abstract}
Background: Boron neutron capture therapy (BNCT) selectively kills tumor cells while sparing adjacent normal cells. Boric acid (BA)-mediated BNCT showed therapeutic efficacy in treating hepatocellular carcinoma (HCC) in vivo. However, DNA damage and corresponding responses induced by BA-mediated BNCT remained unclear. This study aimed to investigate whether BA-mediated BNCT induced DNA double-strand breaks (DSBs) and to explore DNA damage responses in vitro. Materials and Methods: Huh7 Human HCC cells were treated with $B A$ and irradiated with neutrons during $B A-B N C T$. Cell survival and DNA DSBs were examined by clonogenic assay and expression of phosphorylated H2A histone family member $X(\gamma H 2 A X)$, respectively. The DNA damage response was explored by determining the expression levels of DNA repair-and apoptosis-associated proteins and conducting a cell-cycle analysis. Results: DNA DSBs induced by BAmediated BNCT were primarily repaired through the homologous recombination pathway. BA-mediated BNCT induced $G_{2} / M$ arrest and apoptosis in HCC. Conclusion: Our findings may enable the identification of radiosensitizers or adjuvant drugs for potentiating the therapeutic effectiveness of BA-mediated BNCT for HCC.
\end{abstract}

Hepatocellular carcinoma (HCC) is ranked as the sixth most prevalent cancer in the world and largely accounts for cancer-related death, with an 18\% 5-year survival rate $(1,2)$. The poor prognosis is the result of patients with intermediate

*These Authors contributed equally to this study.

Correspondence to: Professor Yung-Jen Chuang, Department of Medical Science and Institute of Bioinformatics and Structural Biology, National Tsing Hua University, Hsinchu, Taiwan, R.O.C. E-mail: yjchuang@life.nthu.edu.tw

Key Words: BNCT, Hepatocellular carcinoma, DNA damage, DNA repair. and advanced stage HCC being ineligible for surgical resection. Statistics show that over $80 \%$ of patients with HCC are diagnosed at later stages, when macrovascular invasion or extrahepatic spread has already developed $(3,4)$. Moreover, most patients develop concomitant liver disease, which complicates the treatment strategy. Consequently, there is a need to develop a novel and effective therapy that improves the clinical outcome of advanced HCC.

Boron neutron capture therapy (BNCT) is a two-step radiation treatment modality that kills tumor cells and leaves normal cells undamaged (5). The procedure starts with the selective accumulation of nonradioactive boron- $10\left({ }^{10} \mathrm{~B}\right)$ containing drugs in the tumor cells. Once a proper tumor-tonormal $(\mathrm{T} / \mathrm{N})$ ratio of ${ }^{10} \mathrm{~B}$ concentration is achieved, the tumor is subjected to low-energy neutron radiation. The ${ }^{10} \mathrm{~B}$ atom captures the neutron, which becomes unstable and subsequently disintegrates, releasing a lithium particle $\left({ }^{7} \mathrm{Li}\right)$ and an alpha particle $\left({ }^{4} \mathrm{He}\right)$ with an energy track shorter than $10 \mu \mathrm{m}$, which is the limit of the diameter of a single cell. Therefore, the particles that result from high linear energy transfer selectively induce destructive effects in cancer cells while sparing adjacent normal cells. Currently, the boron drugs of choice for BNCT are boronophenylalanine and, to a lesser extent, sodium borocaptate. Both drugs have been utilized for BNCT to treat head and neck cancer, high-grade glioblastoma, and malignant melanoma (6-8). However, boronophenylalanine and sodium borocaptate are not favorable for use in BNCT for HCC due to either unwanted boron accumulation in the pancreas or a low $\mathrm{T} / \mathrm{N}$ ratio $(9,10)$. Recently, boric acid (BA), as a promising boron drug for use in BNCT for HCC treatment, demonstrated efficacy and safety when used in both rat and rabbit liver cancer models $(11,12)$. These preclinical studies indicated that BA selectively targeted liver tumors and blood vessels within the tumor or the peritumoral area. Hence, it is important to investigate the mechanisms of action of BAmediated BNCT in HCC.

Radiotherapy is known to induce a wide range of DNA damage to cancer cells, including sugar and base lesions, 
DNA single-strand breaks, and double-strand breaks (DSBs) (13). Upon sensing DNA damage, the DNA damage response (DDR) is elicited to maintain the genomic integrity of the cell. The DDR is a complicated network composed of multiple signal transduction pathways that eventually induces cell-cycle arrest, DNA repair, and cell apoptosis (14).

DSBs are considered the most lethal class of DNA damage because improperly repaired or unrepaired DNA DSBs can result in severe cytotoxic effects (15). DSBs can be directly sensed by the trimeric MRN complex (i.e. MRE11 homolog, double strand break repair nuclease, DNA repair protein RAD50, and nibrin), which further recruits the apical DDR kinase ataxia-telangiectasia mutated (ATM) and ataxiatelangiectasia and protein kinase rad3 (RAD3)-related (ATR) (16). The activation of ATM and ATR leads to phosphorylation of serine ${ }^{139}$ of histone H2AX. The newly phosphorylated $\mathrm{H} 2 \mathrm{AX}$, also called $\gamma \mathrm{H} 2 \mathrm{AX}$, is one of the earliest DNA damage-response meditators in recruiting and localizing DNA-repair proteins (17). In addition, ATM kinase can phosphorylate and activate p53 and checkpoint kinase 2 (CHK2). In turn, p53 increases $p 21$ transcription to inhibit cyclin-dependent kinase 2 (CDK2)/cyclin E, while CHK2 continually activates p53. The resulting inhibition of CDK2/cyclin E eventually activates the G1/S checkpoint and arrests the cell cycle. On the other hand, activated ATR can phosphorylate $\mathrm{CHK} 1$, which promotes the degradation of cell-division cycle 25B (CDC25B) and CDC25C. This action preserves $\mathrm{CDK} 1 /$ cyclin $\mathrm{B}$ kinase in the inactive form, thereby causing $\mathrm{G}_{2} / \mathrm{M}$ cell-cycle arrest (18). Taken together, cell -cycle progression is arrested by checkpoint activation to enable time for the cell to undergo repair. Such action can prevent DNA damage from being passed to the daughter cells. It has been reported that BNCT induces different checkpoints and cell-cycle arrest in glioma stem cells, melanoma cells, and squamous cell carcinoma (19-21). However, it remains unclear whether BA-BNCT affects cellcycle progression in HCC.

Radiation-induced DSBs in higher eukaryotic cells are largely repaired either by homologous recombination (HR) or by nonhomologous end-joining (NHEJ) repair mechanisms (22). In the HR pathway, the MRN complex at the DSB site produces DNA single-strand 3' overhangs by 5' to 3' resection. These single-strand ends are coated initially by replication protein $\mathrm{A}$ and are later replaced by RAD51 recombinase (RAD51) in a process that requires breast cancer susceptibility gene 1 (BRCA1) and BRCA2. The resulting RAD51 nucleoprotein filament infiltrates the homologous DNA to produce a displacement loop consisting of the new heteroduplex DNA. The overhanging 3' end of the single-strand DNA then facilitates DNA synthesis using the heteroduplex DNA as a model template. In terms of the NHEJ pathway, the damage site of the DNA DSB is bound to the lupus KU autoantigen protein p70/p80 (KU70/KU80) heterodimer, which is subsequently attached to DNAdependent protein kinase, catalytic subunit (DNA-PKC) to form a protein complex. DNA ligase IV is then recruited to this protein complex and completes the ligation of the DNA double-strand ends with the help of cofactors $\mathrm{X}$-ray repair cross-complementing protein 4 (XRCC4) and XRCC4-like factor (23).

It has been reported that BNCT produces cancer typespecific DNA damage and repair mechanisms. Specifically, HR is activated in thyroid carcinoma cells, whereas both HR and NHEJ can be activated in melanoma cells after BNCT (24). In terms of HCC, the involvement of HR or NHEJ repair mechanisms in response to BA-BNCT-induced DNA DSBs has yet to be determined.

When DNA damage fails to be repaired, p53, which is activated by ATM/ATR, will initiate the cell apoptotic pathway, followed by caspase-3 activation. Upon enzymatic activation, activated cleaved caspase- 3 promotes subsequent apoptotic events, including DNA fragmentation and cell death (25). Although accumulating evidence has indicated that BNCT can kill cancer cells by inducing apoptosis (26), it is still unclear whether BA-BNCT induces apoptosis of HCC cells, which is important to know for determining the radiobiological effects of BNCT.

In the present study, we aimed to study the DDR induced by BA-mediated BNCT in HCC. Firstly, we examined whether HR or NHEJ is activated in HCC in response to the DNA damage induced by BNCT. We next examined whether BNCT disrupts cell-cycle progression and induces apoptosis in HCC. Our findings with regard to BA-mediated BNCTelicited DDR of HCC cells may reveal how BNCT eliminates HCC cells, enabling the assessment of possible blocking targets to potentiate BNCT efficacy in HCC.

\section{Materials and Methods}

Cell line and cell culture. The Huh7 human HCC cell line (kindly provided by Dr. Hui-Ching Wang, Institute of Molecular and Cellular Biology and Department of Medical Science, National Tsing Hua University, Hsinchu, Taiwan, ROC) were cultured in Dulbecco's modified Eagle's medium (Gibco, Grand Island, NY, USA) supplemented with $10 \%$ heat-inactivated fetal bovine serum, $100 \mu \mathrm{g} / \mathrm{ml}$ penicillin, $100 \mathrm{unit} / \mathrm{ml}$ streptomycin, and $0.25 \mu \mathrm{g} / \mathrm{ml}$ fungizone at $37^{\circ} \mathrm{C}$ in a humidified incubator of $5 \% \mathrm{CO}_{2}$.

Boron solution. ${ }^{10} \mathrm{~B}$-enriched BA $\left(99 \%{ }^{10} \mathrm{~B}\right)$ was purchased from Aldrich Inc. (Darmstadt, Germany). The stock solution of BA was prepared at a concentration of $6000 \mu \mathrm{g} 10^{\mathrm{B}} / \mathrm{ml}$ and stored at $4^{\circ} \mathrm{C}$. The solution was sterilized using a $0.22 \mu \mathrm{m}$ filter.

Boron uptake and quantification. A total of $1 \times 10^{6}$ Huh7 cells were seeded in $10 \mathrm{~cm}$ culture dishes and incubated for $48 \mathrm{~h}$. The cells were then treated with culture medium containing $25 \mu \mathrm{g} 10^{\mathrm{B}} / \mathrm{ml} \mathrm{BA}$ for $0,30,60,90,120$, and $150 \mathrm{~min}$. At each treatment endpoint, the cells were washed with $5 \mathrm{ml}$ phosphate-buffered saline (PBS) three 
times and incubated with $900 \mu$ l Accutase solution (Sigma-Aldrich) for $5 \mathrm{~min}$. After detaching from the culture dish, the cells were weighed, and $600 \mu \mathrm{l}$ medium was added, they were then stored at $4^{\circ} \mathrm{C}$ until boron quantification.

The boron concentration was measured by inductively coupled plasma atomic emission spectroscopy (ICP-AES; OPTIMA 2000 DV; PerkinElmer Instruments, Norwalk, CT, USA). A microwave digestion system (MLS 1200 Milestone, Italy) was used to dissolve the cells into an aqueous solution, which was required for subsequent analysis with the ICP-AES. For microwave decomposition, the cells were treated with $2 \mathrm{ml}$ concentrated nitric acid $(14 \mathrm{~N}, 65 \%)$ and 0.5 $\mathrm{ml}$ hydrogen peroxide (30-35\%) in Teflon high-pressure digestion vessels. The first step in the decomposition process was to digest the samples with $300 \mathrm{~W}$ power for $3 \mathrm{~min}$ and then $600 \mathrm{~W}$ for $2 \mathrm{~min}$, followed by cooling and a 20 min depressurizing step. The digested samples were diluted with deionized water to a final volume of 10 $\mathrm{ml}$ and analyzed by ICP-AES for boron quantification. The boron wavelength was measured at $249.772 \mathrm{~nm}$.

BNCT irradiation. Huh7 cells were seeded at $1.5 \times 10^{5}$ in 6 -well plates and cultured for $48 \mathrm{~h}$. The cells were then treated with culture medium containing $25 \mu \mathrm{g} 10^{\mathrm{B}} / \mathrm{ml}$ BA for $30 \mathrm{~min}$; cells treated with BA-free medium were used as a control. Next, the medium was removed, and the plates were moved to the Tsing Hua Open-pool Reactor (THOR) and inserted into phantoms for neutron irradiation. The control group was also moved to THOR but was not irradiated. The dose rates of the reactor neutron source are shown in Table I. The cells were then irradiated with neutrons for $10 \mathrm{~min}$ and $5 \mathrm{~min}$ for clonogenic assay, and irradiated for $10 \mathrm{~min}$ for use in other experiments. The radiation doses were calculated according to the total dose rates (Table I) and are shown in Table II.

Clonogenic assay. After BNCT irradiation, $1 \times 10^{3}$ cells were reseeded into 6-well plates and cultured for 10-14 days. Next, the cells were washed with PBS and fixed with methanol for 5 min and then stained with $0.1 \%$ crystal violet for $30 \mathrm{~min}$. The cells were then washed with tap water and air-dried. Colonies composed of more than 50 cells were counted. The surviving fraction of the cells was used to quantify cell survival after BNCT treatment. The surviving fraction was defined as the ratio of efficiently plated radiation groups to the efficiently plated non-radiation group. Plating efficiency was defined as the number of colonies divided by the number of the cells seeded.

Immunocytochemistry. The cells were re-seeded on sterile glass coverslips in 6-well culture plates and fixed with $4 \%$ paraformaldehyde/PBS at $6 \mathrm{~h}$ after neutron radiation. The cells were then permeabilized with $0.1 \%$ Triton X-100/PBS and blocked with $3 \%$ bovine serum albumin/PBS for $30 \mathrm{~min}$. The cells were then incubated with antibody to $\gamma \mathrm{H} 2 \mathrm{AX}$ (Ser139; Cell Signaling Technology, Danvers, MA, USA) at $4^{\circ} \mathrm{C}$ overnight, followed by incubation with anti-rabbit IgG-Dylight 488 secondary antibody (Jackson, West Grove, PA, USA). The cell nuclei were stained with Hoechst 33342 (Invitrogen, Carlsbad, CA, USA). After mounting the glass coverslips with anti-fade reagent (Invitrogen), immunofluorescence images were acquired using a confocal microscope (LSM 510 Meta; Zeiss, Oberkochen, Germany).

Cell-cycle analysis. Cells were collected $48 \mathrm{~h}$ after BNCT irradiation and washed twice with PBS. The cells were then fixed in prechilled $75 \%$ ethanol, maintained on ice for $30 \mathrm{~min}$ and stored
Table I. Dose rates of Tsing Hua Open-pool Reactor facility.

\begin{tabular}{lc}
\hline Component & Dose rate (Gy/min) \\
\hline Neutron & $1.53 \times 10^{-2}$ \\
${ }^{10} \mathrm{~B}(\mathrm{n}, \alpha)^{7} \mathrm{Li}$ & $9.3 \times 10^{-3} / \mathrm{ppm}{ }^{10} \mathrm{~B}$ \\
$\mathrm{Gamma}$ & $1.08 \times 10^{-2}$ \\
\hline
\end{tabular}

Table II. Radiation doses for different irradiation times.

\begin{tabular}{lc}
\hline Irradiation time $(\mathrm{min})$ & Total dose $(\mathrm{Gy})$ \\
\hline 5 & 1.148 \\
10 & 2.296 \\
\hline
\end{tabular}

at $-20^{\circ} \mathrm{C}$ until DNA staining. The cells were washed with PBS and then suspended in PI/RNase staining buffer (BD Biosciences, San Jose, CA, USA) and incubated in the dark for $15 \mathrm{~min}$ at room temperature. The percentage of cells at each cell-cycle phase was determined using flow cytometry (BD Accuri C6; BD Biosciences) per the manufacturer's instructions.

Caspase-3 apoptosis assay. Cell apoptosis assay was performed using the PE Active Caspase-3 Apoptosis Kit (BD Biosciences) according to the manufacturer's protocol. Following BNCT irradiation, the cells were harvested at each specified time point and washed twice with cold PBS. The cells were suspended in BD Cytofix/Cytoperm ${ }^{\mathrm{TM}}$ solution and then incubated for $20 \mathrm{~min}$ on ice. Next, the cells were washed twice with BD Perm/Wash ${ }^{\text {TM }}$ buffer and incubated with phycoerythrin (PE)-conjugated anti-active caspase3 antibody in BD Perm/Wash ${ }^{\mathrm{TM}}$ buffer for $30 \mathrm{~min}$ at room temperature. Finally, each sample was washed with and suspended in BD Perm/Wash ${ }^{\mathrm{TM}}$ buffer and then passed through a cell strainer with a $35 \mu \mathrm{m}$ nylon mesh (Falcon, Reynosa, Tamaulipas, Mexico) before measuring caspase- 3 activation with flow cytometry per the manufacturer's instructions.

Western blot analysis. At $4 \mathrm{~h}, 24 \mathrm{~h}$, and $48 \mathrm{~h}$ after BNCT irradiation, total cell lysates were obtained using RIPA lysis buffer (Roche, Indianapolis, IN, USA) containing $1 \mathrm{mM} \mathrm{Na}_{3} \mathrm{VO}_{4}$ (Sigma-Aldrich, St. Louis, MO, USA), $1 \mathrm{mM}$ phenylmethylsulfonyl fluoride (Roche), $10 \mathrm{mM} \mathrm{NaF}$ (Sigma-Aldrich), and 4\% complete protease inhibitor cocktail (Roche). The protein concentration of the lysates was quantified using a bicinchoninic acid protein assay kit (Thermo Scientific). An equal amount of protein was subjected to sodium dodecyl sulfate-polyacrylamide gel electrophoresis and subsequently transferred to polyvinylidene difluoride membranes (Millipore, Darmstadt, Germany). The membranes were then blocked with 3\% BSA in Tris-buffered saline with $0.0005 \%$ Tween-20 (TBST) at room temperature for $1 \mathrm{~h}$, followed by incubation with the following antibodies in $3 \% \mathrm{BSA} / \mathrm{TBST}$ overnight at $4^{\circ} \mathrm{C}$ : $\gamma \mathrm{H} 2 \mathrm{AX}$ (Ser139), BRCA1, RAD51, KU80, KU70 (Cell Signaling Technology), and $\alpha$-tubulin (GeneTex, Hsinchu City, Taiwan, ROC). The membranes were incubated with horseradish peroxidase-conjugated secondary antibodies (GE Healthcare, Buckinghamshire, UK) in 5\% nonfat 
dried milk/TBST for $2 \mathrm{~h}$ at room temperature. After incubation with primary and secondary antibodies, the membranes were washed four times with TBST for $10 \mathrm{~min}$. The protein bands were detected by enhanced chemiluminescence (GE Healthcare) and exposed to film.

Statistical analysis. Data are expressed as the means \pm standard deviation (SD). Statistical comparisons were analyzed by unpaired, two-tailed Student's $t$-test using GraphPad Prism version 6 program (San Diego, CA, USA), and $p<0.05$ was considered statistically significant.

\section{Results}

Time course study of ${ }^{10} B$ uptake in Huh7 human HCC cells. To develop an in vitro irradiation scheme for BA-mediated BNCT of Huh7 cells, we first investigated the cellular uptake of ${ }^{10} \mathrm{~B}$. Huh7 cells were treated with ${ }^{10} \mathrm{BA}$ at a fixed concentration of $25 \mu \mathrm{g} 10^{\mathrm{B}} / \mathrm{ml}$ for $0,30,60,90,120$, and $150 \mathrm{~min}$. The ${ }^{10} \mathrm{~B}$ concentration of the Huh7 cells was then quantified at each time point (Figure 1).

We found that the ${ }^{10} \mathrm{~B}$ concentration rapidly increased from 0 to $22.52 \pm 3.4\left(\mu \mathrm{g}{ }^{10} \mathrm{~B} / \mathrm{g}\right.$ cell $)$ by $30 \mathrm{~min}$. Prolonging the treatment time (i.e., 60, 90, 120, and $150 \mathrm{~min}$ ) did not significantly increase the ${ }^{10} \mathrm{~B}$ uptake by Huh7 cells. Therefore, the Huh7 cells were subjected to neutron radiation after treatment with $25 \mu \mathrm{g} 10^{\mathrm{B}} / \mathrm{ml}{ }^{10} \mathrm{BA}$ for $30 \mathrm{~min}$ in all subsequent experiments in this study.

${ }^{10} B$-BA-mediated BNCT suppresses Huh7 cell survival. After exposure to neutron radiation, Huh7 cell survival was examined by clonogenic assay (Figure 2A). The number of cell colonies was significantly reduced after $5 \mathrm{~min}$ and $10 \mathrm{~min}$ of neutron irradiation compared that of the non-radiation group. To quantify the cell survival status, the surviving fraction plot was used as shown in Figure 2B. The surviving fraction was significantly decreased to $0.13 \pm 0.04$ and $0.07 \pm 0.03$, compared to that of the non-radiation control after $5 \mathrm{~min}$ and $10 \mathrm{~min}$ of irradiation, respectively. These results suggested that BAmediated BNCT significantly inhibited Huh7 cell survival.

${ }^{10}$ B-BA-mediated BNCT induces DNA DSBs in Huh7 cells. To confirm whether ${ }^{10} \mathrm{~B}-\mathrm{BA}$-mediated BNCT induced DSBs in Huh7 cells, immunocytochemistry and western blotting were used to examine the expression of $\gamma \mathrm{H} 2 \mathrm{AX}$, which is the standard biomarker for DSB detection (27).

As expected, the immunocytochemistry results showed that the fluorescence signal of $\gamma \mathrm{H} 2 \mathrm{AX}$ was significantly increased at $6 \mathrm{~h}$ after BNCT compared to the signal observed for the non-radiation control (Figure 3A). To explore the $\gamma \mathrm{H} 2 \mathrm{AX}$ expression profile, the cells were harvested at 4, 24, and $48 \mathrm{~h}$ after BNCT and subjected to western blot analysis (Figure 3B). The results showed that the expression of $\gamma \mathrm{H} 2 \mathrm{AX}$ was rapidly increased and peaked at $4 \mathrm{~h}$ post-BNCT compared to the level of the non-radiation control. The protein expression of $\gamma \mathrm{H} 2 \mathrm{AX}$ was then found to decrease at

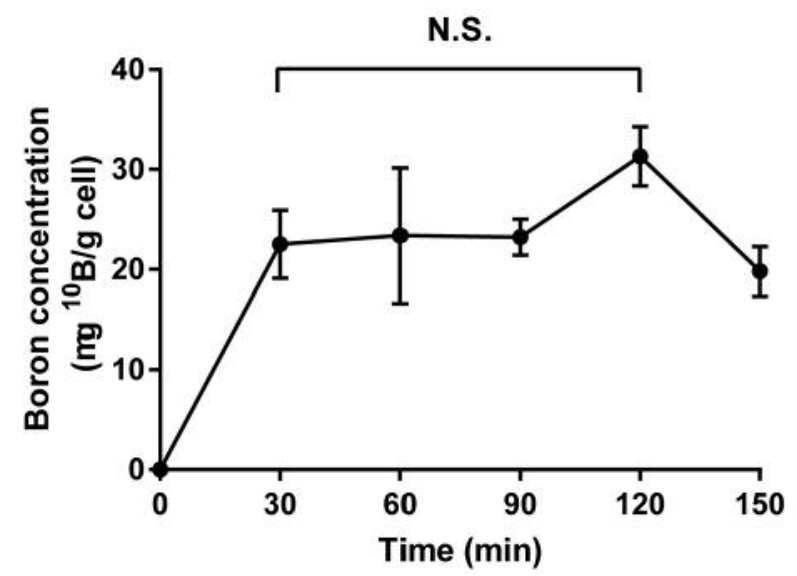

Figure 1. Time course analysis of boron uptake by Huh7 human HCC cells. Huh7 cells were treated with $25 \mu \mathrm{g} 10^{\mathrm{B}} / \mathrm{ml}$ boric acid and assayed at the indicated time points. The cells were then collected and digested by microwave digestion, and the boron concentration of the cells was quantified by inductively coupled plasma-atomic emission spectrometry. N.S.: Not significant.

$24 \mathrm{~h}$ and at $48 \mathrm{~h}$ (Figure 3C). These results indicate that DNA DSBs were dramatically induced within $4 \mathrm{~h}$ following ${ }^{10} \mathrm{~B}-\mathrm{BA}-\mathrm{mediated} \mathrm{BNCT}$. Although not all ${ }^{10} \mathrm{~B}-\mathrm{BA}$-mediated BNCT-induced DNA DSBs were restored, they were found to have been gradually repaired at $24 \mathrm{~h}$ and $48 \mathrm{~h}$.

DNA DSBs induced by ${ }^{10} B-B A-$ mediated BNCT are mainly repaired by $H R$. To further explore which repair mechanism was primarily responsible for the repair of BNCT-induced DSBs in Huh7 cells, we examined the expression of key DNArepair proteins involved in either the HR pathway or the NHEJ pathway at different time points post-BNCT (Figure 4A).

Expression of HR-related proteins BRCA1 and RAD51 was transiently up-regulated following BNCT. Specifically, BRCA1 expression was increased at $4 \mathrm{~h}$ and $24 \mathrm{~h}$, compared to the levels found in the non-radiation control. Notably, BRCA1 expression was sustained at an enhanced level at $48 \mathrm{~h}$. The expression level of RAD51 increased at $4 \mathrm{~h}$ and had a sustained $2.75 \pm 1.45$-fold increase at $24 \mathrm{~h}$. At $48 \mathrm{~h}$ post-BNCT, the RAD51 expression returned to the basal level, on par with that of the non-radiation control. On the other hand, the expression levels of KU70 and KU80, which are marker proteins involved in the NHEJ pathway, displayed no marked change immediately after BNCT. Although the expression level of KU80 decreased to $73 \%$ of the non-radiation control at 48 $\mathrm{h}$ post-BNCT, the expression of KU70 showed no significant change throughout the observation period (Figure 4B).

These results suggested that the HR pathway, but not the NHEJ pathway, was activated in response to ${ }^{10} \mathrm{~B}-\mathrm{BA}-$ mediated BNCT-induced DSBs in Huh7 cells. 
A

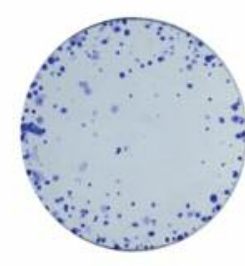

0

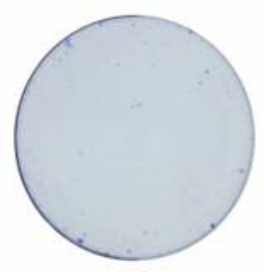

5

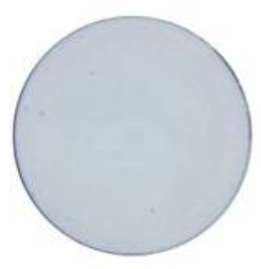

10

\section{Irradiation time (min)}

B

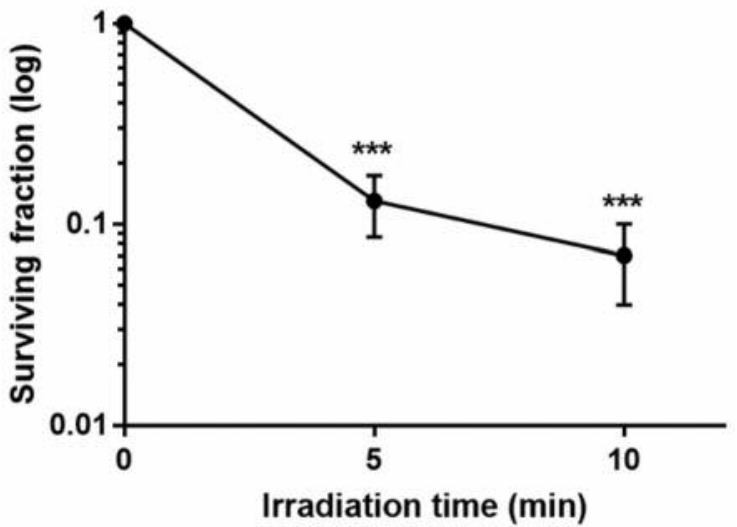

Figure 2. Determination of Huh7 cell survival after ${ }^{10} B$-boric acid-mediated boron neutron capture therapy (BNCT). A: Representative images of the results from the clonogenic assay. Huh7 cells were exposed to 0,5 , and 10 min neutron irradiation, and colonies were visualized by crystal violet staining. $B$ : The surviving fraction of the Huh7 cells after BNCT was calculated based on colony formation. ***Significantly different at p<0.001 vs. control.

A

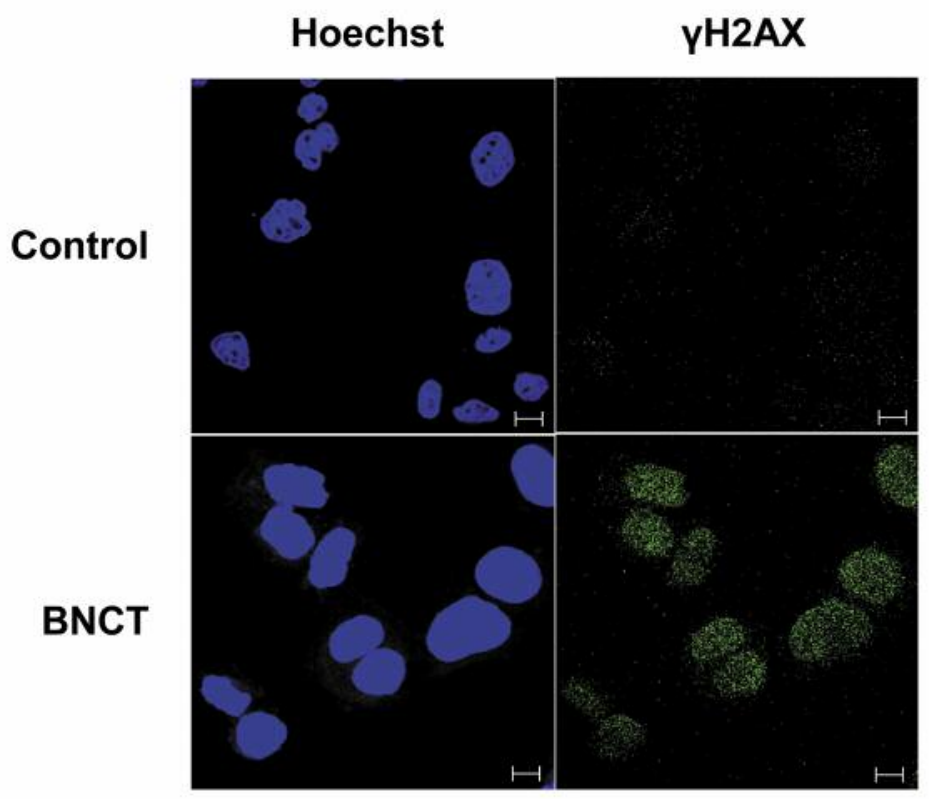

B

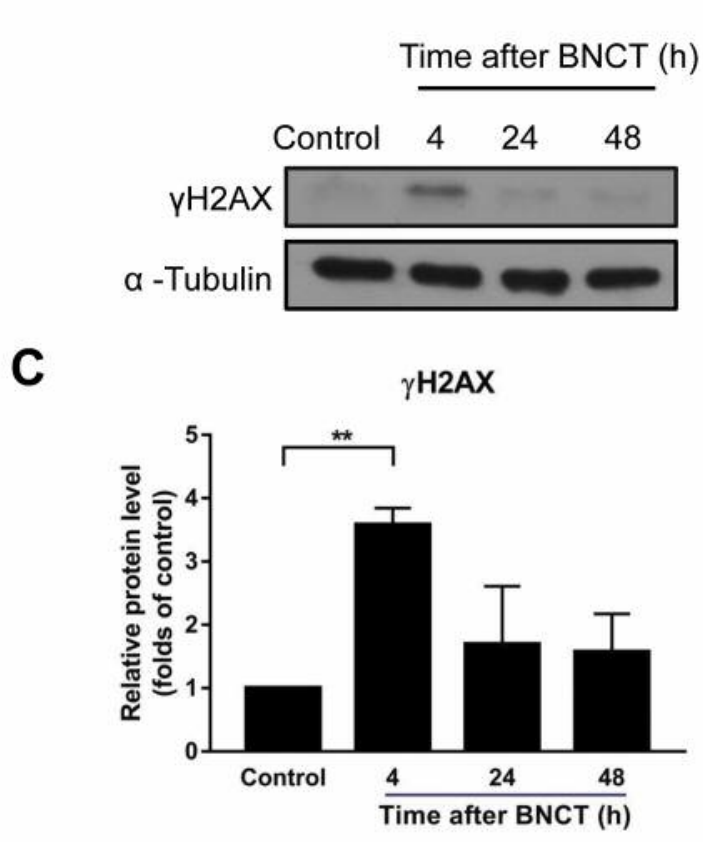

Figure 3. DNA double-strand breaks were induced in Huh7 cells by ${ }^{10}$ B-boric acid-mediated boron neutron capture therapy (BNCT). A: Representative images of phosphorylated H2A histone family member $X(\gamma H 2 A X)$ foci detected by immunocytochemistry 6 h after BNCT. The enhanced $\gamma H 2 A X$ (green) signals accumulated in nuclei (blue), which indicate DNA double-strand breaks. Scale bar=10 $\mu \mathrm{m}$. B: The results from the western blot at different time points after BNCT revealed the dynamic $\gamma H 2 A X$ expression profile. C: The results from the quantitative analysis of $(B)$ were generated by ImageJ software. **Significantly different at $p<0.01 \mathrm{vs}$. control.

${ }^{10} B$-BA-mediated BNCT induces $G_{2} / M$ cell-cycle arrest of Huh7 cells. In addition to DNA-repair pathways, BNCT disrupted cell-cycle progression, causing cell-cycle arrest. Therefore, we continued to explore whether the cell-cycle progression of Huh7 cells was affected by ${ }^{10} \mathrm{~B}-\mathrm{BA}$-mediated BNCT.
We conducted a cell-cycle analysis using PI staining and flow cytometry (Figure 5A). After BNCT, the proportion of Huh7 cells in the sub- $G_{1}$ phase and $S$ phase showed no significant change. However, the proportion of cells in the $\mathrm{G}_{1}$ phase was practically halved after BNCT, while the 


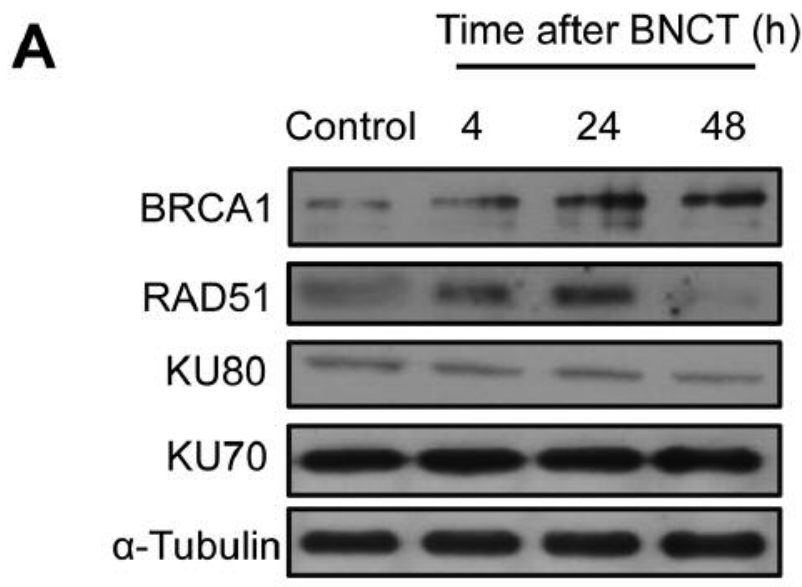

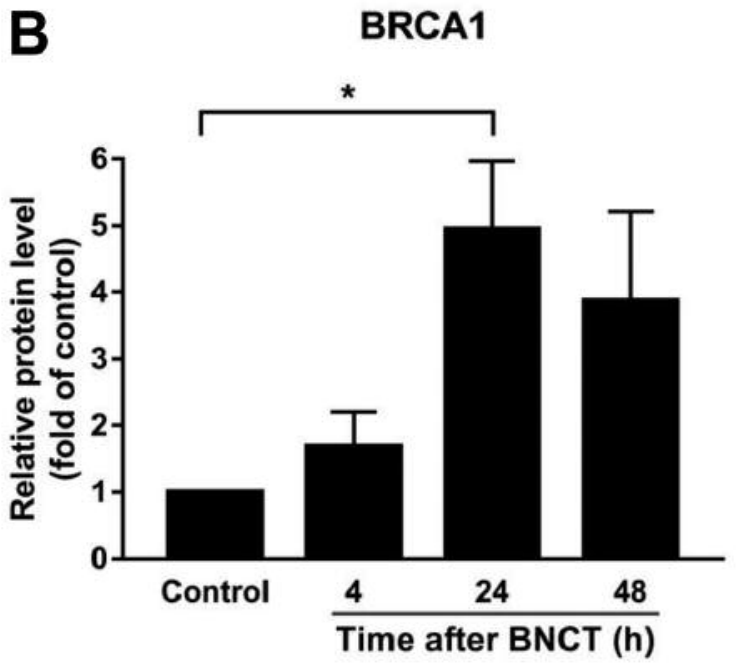

KU80

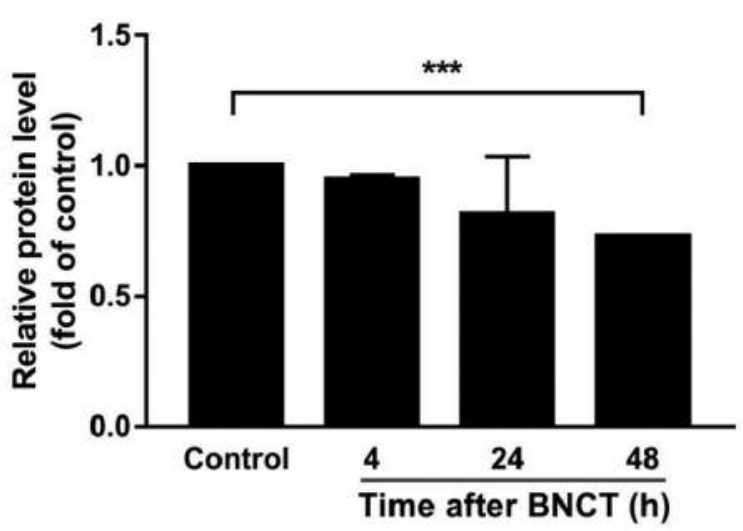

RAD51

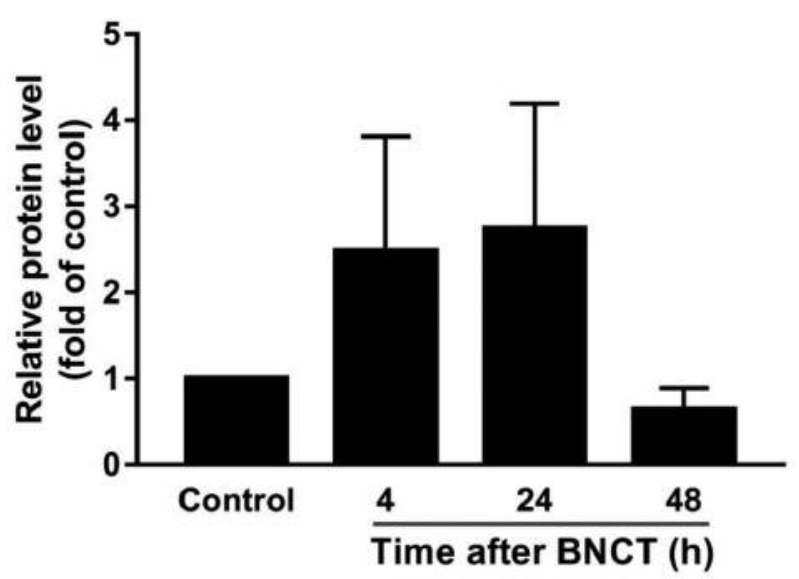

KU70

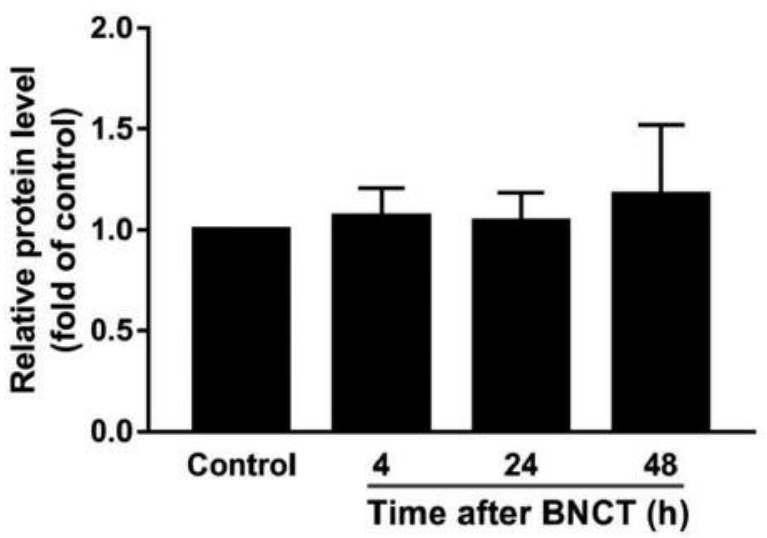

Figure 4. Analysis of homologous recombination (HR)- and non-homologous end-joining (NHEJ)-related proteins expression as a function of time after ${ }^{10}$ B-boric acid-mediated boron neutron capture therapy (BNCT). A: Huh7 cells were harvested at the indicated time points after BNCT and then analyzed by western blotting to determine the dynamic expression of DNA-repair biomarkers. The data displayed the transient expression profiles of HR-related proteins breast cancer susceptibility gene 1 (BRCA1) and RAD51 recombinase (RAD51) after BNCT, while the expression of lupus $K U$ autoantigen protein $p 70 / p 80(K U 70 / K U 80)$, which are NHEJ-related proteins, showed no sign of activation after BNCT. B: The results from the quantitative analysis of $(A)$ were generated by ImageJ software. Significantly different at $* p<0.05$ and $* * * p<0.001$ vs. control. 

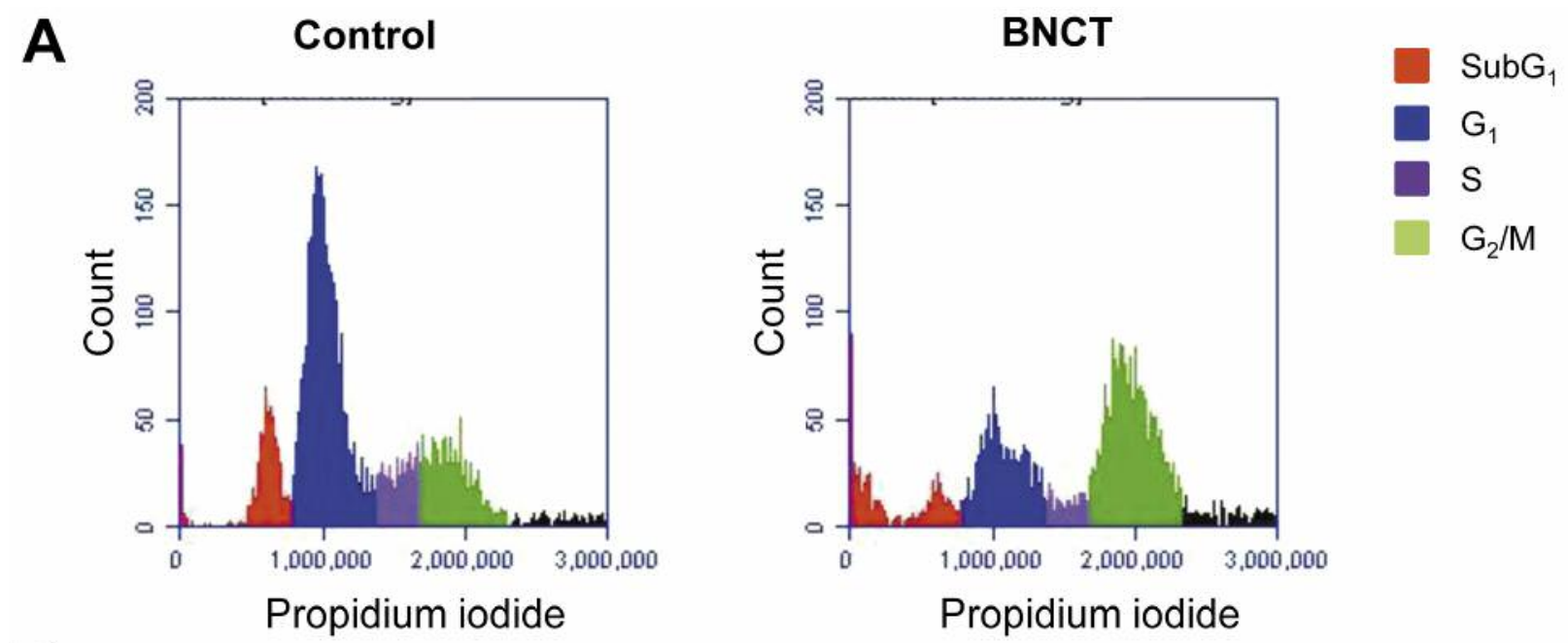

B

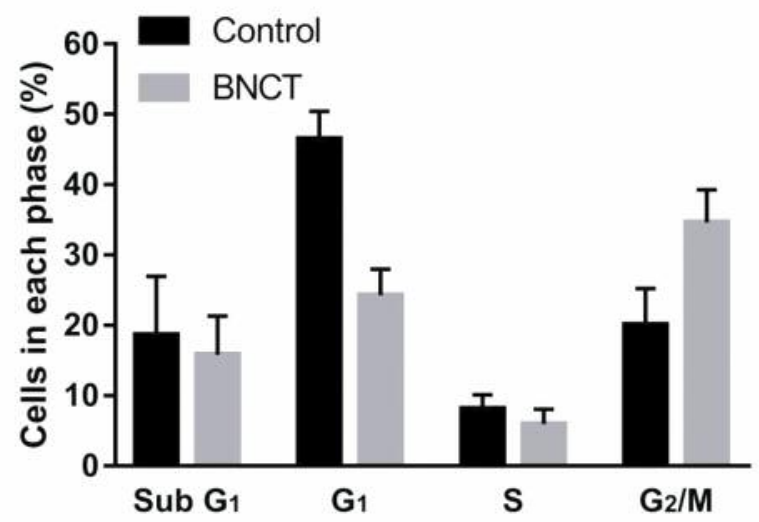

Figure 5. Cell-cycle analysis of Huh7 cells by flow cytometry after ${ }^{10}$ B-boric acid-mediated boron neutron capture therapy (BNCT). A: Huh7 cells were harvested $48 \mathrm{~h}$ after BNCT. Cells were stained by propidium iodide and counted with flow cytometry to produce DNA histogram plots. B: The percentages of cells at each cell-cycle phase were evaluated based on (A).

proportion of cells in the $\mathrm{G}_{2} / \mathrm{M}$ phase increased 1.5 -fold (Figure 5B).

These results indicated that the cell cycle of Huh7 cells was arrested at the $\mathrm{G}_{2} / \mathrm{M}$ checkpoint following ${ }^{10} \mathrm{BA}$ mediated BNCT.

${ }^{10}$ B-BA-mediated BNCT induces cell apoptosis with caspase3 activation. With severe DNA damage beyond repair, cancer cells undergo apoptosis. Hence, we verified whether the killing mechanisms of ${ }^{10} \mathrm{~B}-\mathrm{BA}$-mediated BNCT on Huh7 cells were associated with cell apoptosis.

The level of activated caspase-3, which is a marker of apoptosis, was examined by flow cytometry (Figure 6A). The data showed that caspase-3 fluorescence intensity correspondingly increased at $24 \mathrm{~h}$ and $48 \mathrm{~h}$ after BNCT (Figure 6B).
These results suggested that in addition to DNA damage, ${ }^{10} \mathrm{~B}-\mathrm{BA}-\mathrm{mediated} \mathrm{BNCT}$ indeed induced apoptosis of Huh7 cells with activation of caspase-3.

\section{Discussion}

BNCT has been used in the clinic to eliminate or inhibit the growth of many cancer types, including glioma, head and neck cancer, and malignant melanoma. However, cancer of the abdominal organs, including $\mathrm{HCC}$, are rarely treated with BNCT. The first extracorporeal application of BNCT to liver was performed in 2001 (28). The liver was taken from the patient and transported to a reactor facility for neutron irradiation ex vivo. The liver was then transplanted back into the patient. This BNCT study for treating multiple liver metastases demonstrated the feasibility of using BNCT to treat 


\section{A}

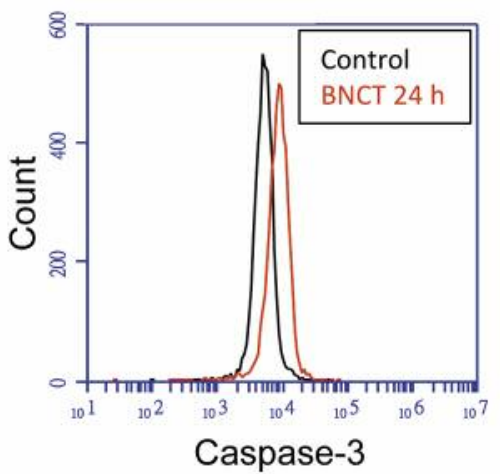

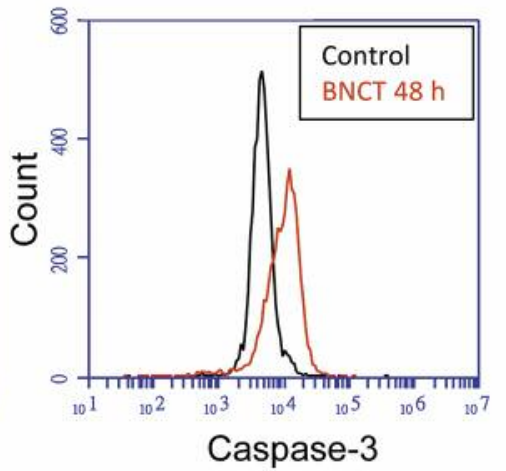

B

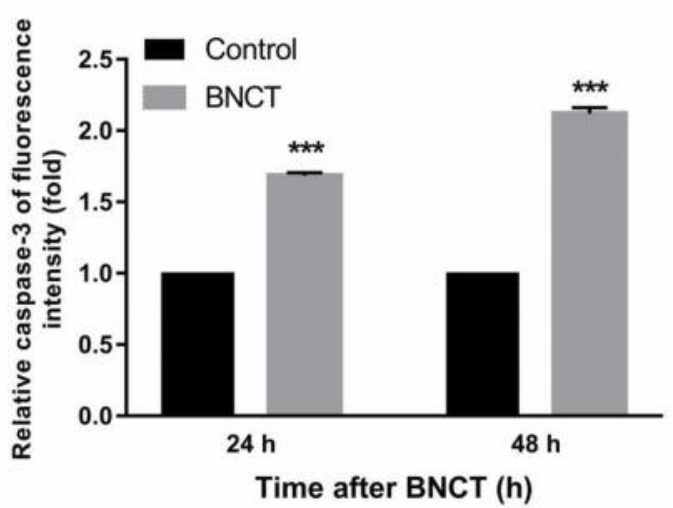

Figure 6. Apoptosis and caspase-3 activity analysis of Huh7 cells after ${ }^{10}$ B-boric acid-mediated boron neutron capture therapy (BNCT). A: Huh7 cells were harvested $24 \mathrm{~h}$ and $48 \mathrm{~h}$ after BNCT for flow cytometric analysis through which the presence of apoptotic cells was measured by the level of activated caspase-3, as indicated by phycoerythrin-stained activated caspase-3. B: The bar graph presents the normalized quantitative statistical analysis of $(A) .{ }^{*} * *$ Significantly different at $p<0.001 \mathrm{vs}$. control.

liver cancer. However, such a high-risk operative procedure impedes its clinical use. Hence, subsequent efforts have mostly focused on developing new ${ }^{10} \mathrm{~B}$ compounds and drug-delivery methods. Yanagie et al. developed a boron carrier called ${ }^{10} \mathrm{~B}-$ BSH-entrapped water-in-oil-in-water (WOW) emulsion for BNCT for use treating liver cancer (29). By intra-arterial injection, ${ }^{10} \mathrm{BSH}$-WOW-mediated BNCT showed significant suppression of liver tumor growth and killing effects in cancer cells of mouse models of liver cancer. Additionally, ${ }^{10} \mathrm{~B}$-BAmediated BNCT has been found to be safe with therapeutic efficacy for treating HCC $(11,12)$. Nevertheless, few studies have clarified the anticancer effects of ${ }^{10} \mathrm{~B}$-BA-mediated $\mathrm{BNCT}$ on $\mathrm{HCC}$. In the present study, we carried out in vitro analysis to quantify the inhibitory effects of ${ }^{10} \mathrm{~B}$-BA-mediated BNCT on the cell survival of human HCC Huh7 cells (Figure $2)$. These results are consistent with previous animal studies $(11,12)$, which strongly supported that ${ }^{10} \mathrm{~B}-\mathrm{BA}$-mediated BNCT as an effective treatment for HCC.

HR and NHEJ are two major pathways by which eukaryotic cells repair DNA DSBs (22). In HR, the repair of broken DNA is completed using homologous DNA as a template. This process results in relative accurate and errorfree repair. NHEJ, on the other hand, is a less accurate and error-prone repair mechanism because broken DNA ends that are compatible are simply ligated with each other. When investigating the repair pathways induced by ${ }^{10} \mathrm{~B}-\mathrm{BA}-$ mediated BNCT in Huh7 cells, we observed a rapid increase in protein expression of BRCA1 and RAD51 after BNCT, both of which are crucial molecules involved in the HR pathway. In contrast, the protein expression of KU70 and KU80, the main components of the NHEJ pathway, did not significantly increase compared to the non-radiation control

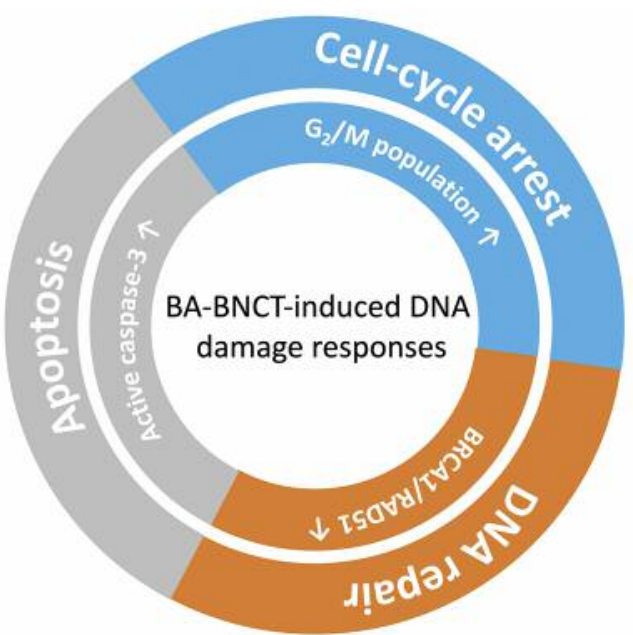

Figure 7. Proposed scheme for ${ }^{10} B$-boric acid (BA)-mediated boron neutron capture therapy (BNCT)-induced DNA damage responses in hepatocellular carcinoma (HCC). ${ }^{10} B-B A$-mediated BNCT induces DNA damage, such as DNA double-strand breaks (DSBs), in human HCC cells. In response to DNA DSBs, caspase-3 is activated to trigger cell apoptosis, leading to cell death. The cell cycle of HCC cells is arrested at the $G_{2} / M$ checkpoint after BNCT, during which time cells use the homologous recombination pathway to repair the DNA DSBS. BRCA1: Breast cancer susceptibility gene 1; RAD51: RAD51 recombinase.

(Figure 4). Together, these results demonstrated that in Huh7 cells, the HR pathway is responsible for DNA DSB repair after ${ }^{10} \mathrm{~B}$-BA-mediated BNCT. Although HR activation has been reported in cancer cells after BNCT, it is still unclear what exactly induces the activation of HR pathway. It has been proposed that the cell-cycle checkpoint plays a critical 
role in the fate of DNA repair, and the tumor suppressor protein, carboxy-terminal binding protein interacting protein, may mediate the activation of HR for DNA DSB repair (30, $31)$. Since it requires intact homologous DNA to serve as a template for completing the repair, HR can only be activated in the late $\mathrm{S}$ and $\mathrm{G}_{2} / \mathrm{M}$ phase, at which time the DNA has already been duplicated (32). This knowledge is consistent with our findings from the cell-cycle analysis, which showed that Huh7 cells were arrested at the $\mathrm{G}_{2} / \mathrm{M}$ checkpoint after ${ }^{10} \mathrm{~B}-\mathrm{BA}$-mediated BNCT (Figure 5).

As shown in Figure 4, increased expression of BRCA1 was sustained through $48 \mathrm{~h}$ post-BNCT, when RAD51 expression had already returned to the basal level. This finding implied that, in addition to the HR pathway, BRCA1 had another function $48 \mathrm{~h}$ after BNCT. It has been reported that BRCA1 functions in DNA damage-induced cell-cycle arrest (33). Specifically, BRCA1 serves as a scaffold protein to facilitate p53 phosphorylation by ATM (34). Phosphorylated p53 then induces the increase of $p 21$ transcription, eventually leading to $G_{1} / S$ arrest. In addition to the $G_{1} / S$ checkpoint, BRCA1 also plays an important role in the $\mathrm{G}_{2} / \mathrm{M}$ checkpoint. ATM can phosphorylate $\operatorname{Ser}^{1423}$ of BRCA1, which is necessary for activating the $\mathrm{G}_{2} / \mathrm{M}$ checkpoint (35). This is in agreement with our results indicating that Huh7 cells arrest in $\mathrm{G}_{2} / \mathrm{M}$ phase 48 $\mathrm{h}$ post-BNCT. More experiments are needed to verify how BRCA1 contributes to $\mathrm{G}_{2} / \mathrm{M}$ cell-cycle arrest after ${ }^{10} \mathrm{~B}-\mathrm{BA}$ mediated BNCT.

Apoptosis is a well-known process of programmed cell death and is considered an important mechanism of action in radiation-induced cell death (36) such that it may contribute to the therapeutic efficacy of BNCT. Lee et al. found a correlation between the extent of radiation-induced apoptosis and cellular radiosensitivity (37). With the knowledge that BNCT acts primarily through particles of linear energy transfer, ${ }^{7} \mathrm{Li}$ and ${ }^{4} \mathrm{He}$, we investigated whether ${ }^{10} \mathrm{~B}-\mathrm{BA}$ mediated BNCT induced apoptosis of HCC cells. We observed that apoptosis was induced in Huh7 cells $24 \mathrm{~h}$ and $48 \mathrm{~h}$ post-BNCT. Furthermore, activated caspase-3, a marker of apoptotic cell death, was also significantly induced $24 \mathrm{~h}$ and $48 \mathrm{~h}$ after BNCT (Figure 6). These results confirmed that ${ }^{10} \mathrm{~B}-\mathrm{BA}-$ mediated BNCT induces apoptosis of Huh7 human HCC cells, which reduced Huh7 cell survival.

Despite many promising clinical uses of BNCT in treating cancer, it may be possible to further improve tumor response by combining BNCT with other treatments. Radiation induces the DDR in the cells, which can lead to apoptosis, cell-cycle arrest, and DNA repair. Among these mechanisms, cell-cycle arrest and DNA repair are considered pro-survival events, and both help cancer cells survive radiation-induced cytotoxic effects. Recently, many studies have sought to target DDR pathways and cell-cycle checkpoint signaling to improve the therapeutic efficacy of radiotherapy (38). In the present study, we found that Huh7 HCC cells were arrested in the $\mathrm{G}_{2} / \mathrm{M}$ cell-cycle phase after ${ }^{10} \mathrm{~B}$-BA-mediated BNCT. We wondered whether $\mathrm{G}_{2} / \mathrm{M}$ checkpoint inhibition has the potential to sensitize Huh7 cells to BNCT. After literature survey, we found that ATR and CHK1 inhibitors may be promising candidates. It is worth mentioning that there are four ATR inhibitors and three CHK1 inhibitors currently undergoing clinical trials, mostly in combination with genotoxic chemotherapy or ionizing radiation (39). In addition, we also found that the primary pathway for repair of BNCTinduced DNA DSBs was HR. As a result, inhibitors targeting the involved components (namely RAD51, ATR, and CHK1) may potentiate BNCT efficacy by blocking the HR pathway and $\mathrm{G}_{2} / \mathrm{M}$ checkpoint activation (40).

\section{Conclusion}

This study showed that ${ }^{10} \mathrm{~B}-\mathrm{BA}$-mediated BNCT effectively inhibited the growth of Huh7 human HCC cells by inducing DNA DSBs and apoptosis. Moreover, our data also suggest that $\mathrm{HCC}$ cells may undergo $\mathrm{G}_{2} / \mathrm{M}$ cell-cycle arrest and use the HR pathway to repair the BNCT-induced DNA DSBs (Figure 7). Further understanding of ${ }^{10} \mathrm{~B}-\mathrm{BA}$-mediated BNCT-induced DDR mechanisms will ultimately contribute to potentiating therapeutic effectiveness against HCC.

\section{Conflicts of Interest}

The Authors declare that they have no competing interests in regard to this study.

\section{Authors' Contributions}

KH Chen carried out the experiments, analyzed the data, and drafted the article. ZY Lai performed the experiments and helped with neutron irradiation. DY Li helped with neutron irradiation. YC Lin and FI Chou provided the phantoms and organized the irradiation procedure. YJ Chuang conceived and coordinated the study.

\section{Acknowledgements}

This study was supported by Ministry of Science and Technology, Taiwan, R.O.C. under Grant No. MOST 106-2311-B-007-009-MY3.

\section{References}

1 Jemal A, Ward EM, Johnson CJ, Cronin KA, Ma J, Ryerson B, Mariotto A, Lake AJ, Wilson R, Sherman RL, Anderson RN, Henley SJ, Kohler BA, Penberthy L, Feuer EJ and Weir HK: Annual report to the nation on the status of cancer, 1975-2014, featuring survival. J Natl Cancer Inst 109(9), 2017. PMID: 28376154. DOI: $10.1093 /$ jnci/djx030

2 Villanueva A: Hepatocellular carcinoma. Reply. N Engl J Med 381(1): e2, 2019. PMID: 31269387. DOI: 10.1056/NEJMc 1906565

3 Ahn SM, Jang SJ, Shim JH, Kim D, Hong SM, Sung CO, Baek D, Haq F, Ansari AA, Lee SY, Chun SM, Choi S, Choi HJ, Kim 
J, Kim S, Hwang S, Lee YJ, Lee JE, Jung WR, Jang HY, Yang E, Sung WK, Lee NP, Mao M, Lee C, Zucman-Rossi J, Yu E, Lee $\mathrm{HC}$ and Kong G: Genomic portrait of resectable hepatocellular carcinomas: Implications of RB1 and FGF19 aberrations for patient stratification. Hepatology 60(6): 19721982, 2014. PMID: 24798001. DOI: 10.1002/hep.27198

4 Crissien AM and Frenette C: Current management of hepatocellular carcinoma. Gastroenterol Hepatol 10(3): 153-161, 2014. PMID: 24829542.

5 Nedunchezhian K, Aswath N, Thiruppathy $\mathrm{M}$ and Thirugnanamurthy S: Boron neutron capture therapy - a literature review. J Clin Diagn Res 10(12): ZE01-ZE04, 2016. PMID: 28209015. DOI: $10.7860 / \mathrm{JCDR} / 2016 / 19890.9024$

6 Barth RF, Vicente MG, Harling OK, Kiger WS, 3rd, Riley KJ, Binns PJ, Wagner FM, Suzuki M, Aihara T, Kato I and Kawabata S: Current status of boron neutron capture therapy of high-grade gliomas and recurrent head and neck cancer. Radiat Oncol 7: 146, 2012. PMID: 22929110. DOI: 10.1186/1748-717X-7-146

7 Wang LW, Liu YH, Chou FI and Jiang SH: Clinical trials for treating recurrent head and neck cancer with boron neutron capture therapy using the Tsing-Hua open pool reactor. Cancer Commun 38(1): 37, 2018. PMID: 29914577. DOI: 10.1186/ s40880-018-0295-y

8 Menendez PR, Roth BM, Pereira MD, Casal MR, Gonzalez SJ, Feld DB, Santa Cruz GA, Kessler J, Longhino J, Blaumann H, Jimenez Rebagliati R, Calzetta Larrieu OA, Fernandez C, Nievas SI and Liberman SJ: BNCT for skin melanoma in extremities: Updated Argentine clinical results. Appl Radiat Isot 67(7-8 Suppl): S50-53, 2009. PMID: 19375342. DOI: 10.1016/ j.apradiso.2009.03.020

9 Suzuki M, Masunaga S, Kinashi Y, Nagata K, Sakurai Y, Nakamatsu K, Nishimura Y, Maruhashi A and Ono K: Intraarterial administration of sodium borocaptate (BSH)/lipiodol emulsion delivers B-10 to liver tumors highly selectively for boron neutron capture therapy: Experimental studies in the rat liver model. Int J Radiat Oncol Biol Phys 59(1): 260-266, 2004. PMID: 15093923. DOI: 10.1016/j.ijrobp.2003.12.018

10 Chou FI, Chung HP, Liu HM, Chi CW and Lui WY: Suitability of boron carriers for BNCT: Accumulation of boron in malignant and normal liver cells after treatment with BPA, BSH and BA. Appl Radiat Isot 67(7-8 Suppl): S105-108, 2009. PMID: 19375330. DOI: $10.1016 /$ j.apradiso.2009.03.025

11 Lin SY, Lin CJ, Liao JW, Peir JJ, Chen WL, Chi CW, Lin YC, Liu YM and Chou FI: Therapeutic efficacy for hepatocellular carcinoma by boric acid-mediated boron neutron capture therapy in a rat model. Anticancer Res 33(11): 4799-4809, 2013. PMID: 24222116.

12 Yang CH, Lin YT, Hung YH, Liao JW, Peir JJ, Liu HM, Lin YL, Liu YM, Chen YW, Chuang KS and Chou FI: Autoradiographic and histopathological studies of boric acid-mediated BNCT in hepatic VX2 tumor-bearing rabbits: Specific boron retention and damage in tumor and tumor vessels. Appl Radiat Isot 106: 176180, 2015. PMID: 26372198. DOI: 10.1016/j.apradiso.2015.08.034

13 Maier P, Hartmann L, Wenz F and Herskind C: Cellular pathways in response to ionizing radiation and their targetability for tumor radiosensitization. Int J Mol Sci 17(1), 2016. PMID: 26784176. DOI: 10.3390/ijms17010102

14 Zhou BB and Elledge SJ: The DNA damage response: Putting checkpoints in perspective. Nature 408(6811): 433-439, 2000. PMID: 11100718. DOI: $10.1038 / 35044005$
15 Wang H, Zhang X, Wang P, Yu X, Essers J, Chen D, Kanaar R, Takeda S and Wang Y: Characteristics of DNA-binding proteins determine the biological sensitivity to high-linear energy transfer radiation. Nucleic Acids Res 38(10): 3245-3251, 2010. PMID: 20150414. DOI: $10.1093 / \mathrm{nar} / \mathrm{gkq} 069$

16 Czornak K, Chughtai S and Chrzanowska KH: Mystery of DNA repair: The role of the MRN complex and ATM kinase in DNA damage repair. J Appl Genet 49(4): 383-396, 2008. PMID: 19029686. DOI: $10.1007 / \mathrm{BF} 03195638$

17 Burma S, Chen BP, Murphy M, Kurimasa A and Chen DJ: Atm phosphorylates histone H2AX in response to DNA double-strand breaks. J Biol Chem 276(45): 42462-42467, 2001. PMID: 11571274. DOI: $10.1074 /$ jbc.C100466200

18 Sorensen CS, Syljuasen RG, Falck J, Schroeder T, Ronnstrand L, Khanna KK, Zhou BB, Bartek J and Lukas J: CHK1 regulates the $\mathrm{S}$ phase checkpoint by coupling the physiological turnover and ionizing radiation-induced accelerated proteolysis of CDC25A. Cancer Cell 3(3): 247-258, 2003. PMID: 12676583. DOI: $10.1016 / \mathrm{s} 1535-6108(03) 00048-5$

19 Kamida A, Fujita Y, Kato I, Iwai S, Ono K, Suzuki M, Sakurai $\mathrm{Y}$ and Yura Y: Effect of neutron capture therapy on the cell cycle of human squamous cell carcinoma cells. Int J Radiat Biol 84(3): 191-199, 2008. PMID: 18300019. DOI: 10.1080/095530008 01902125

20 Sun T, Zhang Z, Li B, Chen G, Xie X, Wei Y, Wu J, Zhou Y and $\mathrm{Du} \mathrm{Z}$ : Boron neutron capture therapy induces cell-cycle arrest and cell apoptosis of glioma stem/progenitor cells in vitro. Radiat Oncol 8(1): 195, 2013. PMID: 23915425. DOI: 10.1186/1748-717X-8-195

21 Faiao-Flores F, Coelho PR, Arruda-Neto J and Maria DA: Boron neutron capture therapy induces cell cycle arrest and DNA fragmentation in murine melanoma cells. Appl Radiat Isot 69(12): 1741-1744, 2011. PMID: 21441034. DOI: 10.1016/j.apradiso.2011.03.005

22 Pfeiffer P, Goedecke W and Obe G: Mechanisms of DNA double-strand break repair and their potential to induce chromosomal aberrations. Mutagenesis 15(4): 289-302, 2000. PMID: 10887207. DOI: 10.1093/mutage/15.4.289

23 Rassool FV and Tomkinson AE: Targeting abnormal DNA doublestrand break repair in cancer. Cell Mol Life Sci 67(21): 3699-3710, 2010. PMID: 20697770. DOI: 10.1007/s00018-010-0493-5

24 Rodriguez C, Carpano M, Curotto P, Thorp S, Casal M, Juvenal G, Pisarev M and Dagrosa MA: In vitro studies of DNA damage and repair mechanisms induced by BNCT in a poorly differentiated thyroid carcinoma cell line. Radiat Environ Biophys 57(2): 143152, 2018. PMID: 29453554. DOI: 10.1007/s00411-017-0729-y

25 Amaral JD, Xavier JM, Steer CJ and Rodrigues CM: The role of p53 in apoptosis. Discov Med 9(45): 145-152, 2010. PMID: 20193641.

26 Wang P, Zhen H, Jiang X, Zhang W, Cheng X, Guo G, Mao X and Zhang $\mathrm{X}$ : Boron neutron capture therapy induces apoptosis of glioma cells through BCL2/BAX. BMC Cancer 10: 661, 2010. PMID: 21122152. DOI: 10.1186/1471-2407-10-661

27 Kuo LJ and Yang LX: Gamma-H2AX - a novel biomarker for DNA double-strand breaks. In Vivo 22(3): 305-309, 2008. PMID: 18610740.

28 Zonta A, Prati U, Roveda L, Ferrari C, Zonta S, Clerici AM, Zonta C, Pinelli T, Fossati F and Altieri S: Clinical lessons from the first applications of BNCT on unresectable liver metastases. J Phys Conf Ser 41: 484-495, 2006. DOI: 10.1088/17426596/41/1/054 
29 Yanagie H, Dewi N, Higashi S, Ikushima I, Seguchi K, Mizumachi R, Murata Y, Morishita Y, Shinohara A, Mikado S, Yasuda N, Fujihara M, Sakurai Y, Mouri K, Yanagawa M, Iizuka T, Suzuki M, Sakurai Y, Masunaga SI, Tanaka H, Matsukawa T, Yokoyama K, Fujino T, Ogura K, Nonaka Y, Sugiyama H, Kajiyama T, Yui S, Nishimura R, Ono K, Takamoto S, Nakajima J, Ono M, Eriguchi M, Hasumi K and Takahashi H: Selective boron delivery by intra-arterial injection of BSH-WOW emulsion in hepatic cancer model for neutron capture therapy. Br J Radiol 90(1074): 20170004, 2017. PMID: 28406315. DOI: 10.1259/bjr.20170004

30 Jeggo $\mathrm{P}$ and Lobrich M: Radiation-induced DNA damage responses. Radiat Prot Dosimetry 122(1-4): 124-127, 2006. PMID: 17351270 . DOI: $10.1093 / \mathrm{rpd} / \mathrm{ncl} 495$

31 You Z and Bailis JM: DNA damage and decisions: Ctip coordinates DNA repair and cell cycle checkpoints. Trends Cell Biol 20(7): 402-409, 2010. PMID: 20444606. DOI: 10.1016/j.tcb.2010.04.002

32 Sonoda E, Hochegger H, Saberi A, Taniguchi Y and Takeda S: Differential usage of non-homologous end-joining and homologous recombination in double strand break repair. DNA Repair 5(9-10): 1021-1029, 2006. PMID: 16807135. DOI: 10.1016/j.dnarep.2006.05.022

$33 \mathrm{Wu}$ J, Lu LY and Yu X: The role of BRCA1 in DNA damage response. Protein Cell 1(2): 117-123, 2010. PMID: 21203981. DOI: $10.1007 / \mathrm{s} 13238-010-0010-5$

34 Fabbro M, Savage K, Hobson K, Deans AJ, Powell SN, McArthur GA and Khanna KK: BRCA1-BARD1 complexes are required for $p 53$ ser- 15 phosphorylation and a $\mathrm{G}_{1} / \mathrm{s}$ arrest following ionizing radiation-induced DNA damage. J Biol Chem 279(30): 31251-31258, 2004. PMID: 15159397. DOI: $10.1074 / \mathrm{jbc} . \mathrm{M} 405372200$
$35 \mathrm{Xu}$ B, Kim S and Kastan MB: Involvement of BRCA1 in Sphase and $\mathrm{G}_{2}$-phase checkpoints after ionizing irradiation. Mol Cell Biol 21(10): 3445-3450, 2001. PMID: 11313470. DOI: 10.1128/MCB.21.10.3445-3450.2001

36 Verheij $M$ and Bartelink H: Radiation-induced apoptosis. Cell Tissue Res 301(1): 133-142, 2000. PMID: 10928286. DOI: $10.1007 / \mathrm{s} 004410000188$

37 Lee HJ, Kim JS, Moon C, Kim JC, Jo SK and Kim SH: Relative biological effectiveness of fast neutrons in a multiorgan assay for apoptosis in mouse. Environ Toxicol 23(2): 233-239, 2008. PMID: 18214905 . DOI: $10.1002 /$ tox.20328

38 Hein AL, Ouellette MM and Yan Y: Radiation-induced signaling pathways that promote cancer cell survival (review). Int J Oncol 45(5): 1813-1819, 2014. PMID: 25174607. DOI: 10.3892/ijo. 2014.2614

39 Dillon MT, Good JS and Harrington KJ: Selective targeting of the $\mathrm{G}_{2} / \mathrm{m}$ cell cycle checkpoint to improve the therapeutic index of radiotherapy. Clin Oncol 26(5): 257-265, 2014. PMID: 24581946. DOI: 10.1016/j.clon.2014.01.009

40.Hengel SR, Spies MA and Spies M: Small-molecule inhibitors targeting DNA repair and DNA repair deficiency in research and cancer therapy. Cell Chem Biol 24(9): 1101-1119, 2017. PMID: 28938088. DOI: 10.1016/j.chembiol.2017.08.027

Received November 3, 2019

Revised November 15, 2019

Accepted November 18, 2019 